\title{
スポーツ傷害の治療（下肢）
}

\section{Physical Therapy for Sports Injury of Lower Extremities}

\section{福井 勉}

TsuTomu FUKUI

College of Medical Sciences, Showa University: 1865 Tokaichiba-cho, Midori-ku, Yokohama, Kanagawa 226-8555, Japan. TEL +81 45-985-6549

Rigakuryoho Kagaku 13(3): 151-155, 1998. Received Jun. 19, 1998.

\begin{abstract}
In sports injury, the pain of the injured point frequently stems from an excessive mechanical stress. Physical therapy for sports injury of lower extremities can be effectively performed with three-step method; in the first step physical therapy for pain relief and remission of inflammation, in the second step conventional physical therapy on the injured point with a primary purpose of reducing the mechanical stress on the point, and in the third step physical therapy for removing causative physical factors of injury. In addition to these, the followings may be taken in consideration; muscle activity highly depends on the posture, limit of range of motion or muscle shortening undoubtedly affects other joints, monarticular muscle shows different motor response from polyarticular muscle, and there is a torque that outside power requires the joint in every movement.
\end{abstract}

Key words: mechanical stress, sports injury, disperformance

要旨 : スポーツ障害では当該部位の疼痛が mechanical stress 過剩で生じることが多い。その理学療法では, 3 段階に分けて考えることは有効である。第1段階は, 症状の中心である疼痛や炎症に対して施行するもので ある。また第2段階として, 傷害された部位に対して行う通常の理学療法を, 負荷部位の mechanical stress 軽滅する目的で行う。第3段階としては, 障害発生原因を追求し, 身体要因を除去できるように展開する必 要がある。その際に, 肢位の違いで筋活動は全く違うこと, 関節可動域制限や筋短縮は必ず他関節へ影響を 与えること, 単関節筋と多関節筋の運動対応の違うこと, 外力が関節に要求するトルクを考慮に入れること が必要ではないだろうか。 キーワード:メカニカルストレス, スポーツ障害, disperformance 


\section{I.はじめに}

スポーツ傷害の治療に関わる理学潦法士は, 選手のコ ンディショニング, 傷害からの現場復帰, あるいはスポー ツ能力自体の向上など様々な場面で理学療法を施行して いる。いずれの場合もスポーツ傷害では該当部位の疼痛 がmechanical stress過剩で生じることが多い。スポーツ外 傷では, mechanical stressの結果として様々な症状を引き 起こすわけだが，スポーツ障害では mechanical stressの 原因となる身体要因, 環境要因が存在する。したがって, スポーツ障害においては mechanical stress そのものの原 因を取り除かない限り, 再発の可能性が大きいと考えら れる。疼痛部位のみの治療をしても, 何故その疼痛が生 じたのかという clinical reasoningそのものへの追求が, 患 者のコンディショニング, 再発予防, はてはスポーツパ フォーマンスと結びつくのではないだろうか。今回，こ の mechanical stress を中心に話をさせていただくことに する。

\section{II. スポーツ傷害の3段階}

スポーツ外傷では 1 回の, スポーツ障害では頻回な mechanical stress が患部に影響している。脛骨の骨折を生 じた原因がスキーによる boots top fracture であればス ポーツ外傷であるが, 通常この外傷は不可抗力で生じて いるために，次回また同じ外傷を起こさないように予防 するのは困難であることが多い。しかし, 疲労骨折によっ て脛骨が骨折した場合, スポーッ障害として, 骨折に至 る原因を取り除ける可能性は大である。特にその原因が 身体要因である場合, 理学療法の責任は大きいと言える。

スポーツ傷害に対して理学療法を行うときに, 外傷で も障害でも 3 つの段階に分けて考えることは有効ではな いだろうか (表 1)。第 1段階は, 症状の中心である疼痛 や炎症に対して施行するものであり, 対症療法である。 また第 2 段階として, 傷害された部位に対して行う通常 の理学療法を, 負荷部位の mechanical stress を軽減する

表 1 スポーツに関する理学療法の段階

第1段階:対症療法もしくは術後管理

疼痛等炎症の軽減，手術後リスク管理

第2段階:障害部位訓練

障害部位と周囲への治療，負荷部位のストレス軽減 第3段階:パフォーマンス向上訓練

傷害発生原因の追求, 再発予防など
目的で行う。第3段階としては, 傷害発生原因を追求し, mechanical stress の原因となる身体要因を除去できるよ うに，再発予防を含めたスタイルの理学療法を展開する 必要がある。

\section{Mechanical stress 減少策}

評価によって mechanical stress の大きい部位を決定す ることは非常に重要であるが, 傷害部位のみの評価では 困難である。その理由は, その部位と他の部位との運動 連関が運動学的によくわからないことがあったり, ス ポーツ障害では現実的にどの程度の運動量なのかが不明 確であるためである。傷害部位のmechanical stressを判断 するために有益な運動学的要因をいくつか挙げる。

\section{1. 肢位の違いで筋活動は全く違う}

筋活動は単関節の場合関節角度に依存することが多い が, 力を必要とする運動では, 空間に対しての肢節の位 置関係で決まることが多い。肩関節屈曲 120 度といって も，立位であれば肩関節屈筋が，仰臥位であれば肩関節 伸筋が作用する（図 1)。

2. 関節可動域制限や筋短縮は必ず他関節へ影響を 与える

股関節屈曲可動域制限は, 大抵の場合腰椎屈曲可動域 を大きくする。同様に股関節内転可動域制限は同側の体 幹の伸張可動性を大きくする。これらの身体重心の上下 での運動連関は日常よくみられる。

可動制限が直接連続していない関節に与える影響もあ る。例えば，股関節屈曲可動制限は足関節を背屈位にし， 伸展可動制限は足関節を底屈位にすることが多い（図 2)。これらの違いは詳細な観察によって区別が付くもの

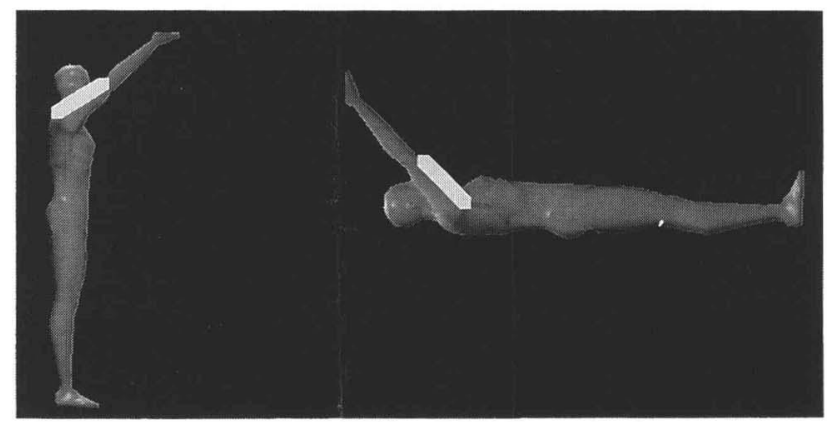

図1 立位と臥位での筋活動の違い 
と考えられる。左右差の詳細な観察をすることにより, 足 関節可動域制限を股関節操作で，あるいは股関節可動制限 を足関節で得られることも珍しくない。

\section{3. 単関節筋と多関節筋の運動対応の違い}

単関節筋では関節の安定性と正しい運動の誘導, 二関 節筋は関節モーメントの多くを担う。そのため関節可動 域を改善したい場合や関節運動が生理的に行われるよう にしたい場合にも，単関節筋のトレーニングが必須にな る。関節運動がスムーズに行われていない場合，その運 動に参加する2関節筋が過剩に働いているケースが多い。 股関節屈曲可動制限がある患者では，屈曲運動における 大腿直筋の割合いが高く，腸腰筋の割合が低くなってい る(図 3)。

\section{4. 外力が関節に要求するトルク}

関節に要求されるトルクが大きくなると，筋長の長い 筋の作用が重要になる。ところが，筋長の長い筋の作用 が優位になると，筋の骨への付着部同士を直線的に近づ けるため，間にある関節に剪力が加わる傾向になる。こ のような運動によって，間にある関節は不安定になり易 くなる。関節面に剪断方向のmechanical stressが作用する ためである。

端座位で背中を伸ばした姿勢で徐々に後方に傾斜する と, 骨盤〜脊柱に要求される屈曲モーメントは非常に大 きくなる。したがって頭や胸椎を屈曲させて，慣性モ一 メントを小さくしようとするのである（図 4）。

そのように脊柱全体が屈曲することによって間にある 椎体間にはより剪断力が作用し，不安定になっていく。 例えば，無分離艺りはこれにあたる。背中を伸ばそうと すればするほど腹直筋の作用よりも腸腰筋，腹横筋など のより深層筋活動が重要となる。これらの筋の活動性を 高めることが安定した関節をつくる重要な方法であると 考えられる。

\section{5. 関節モーメント =筋 + 受動要素 + その他}

関節モーメントをつくるのは筋活動のみではない。特 に重要なのが䩲带, 関節包, 筋膜などの非収縮受動組織 である。

前述の動作と逆を考えてみる。端座位で前傾する場合 を考える。前傾角度が大きくなるに従って，骨盤～脊柱 には伸展モーメントが要求される。脊柱起立筋，特に胸 腸肋筋，胸最長筋などの長い筋がこの運動の主体になる と筋の両端が近づく結果となり，体幹が伸展してしまう （図 5 右）。なるべく頭尾のアライメントを良好に保った

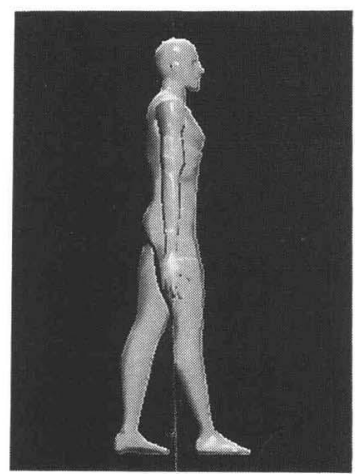

図2 股関節屈曲位と足関節底屈位，股関節伸展位と 足関節背屈位

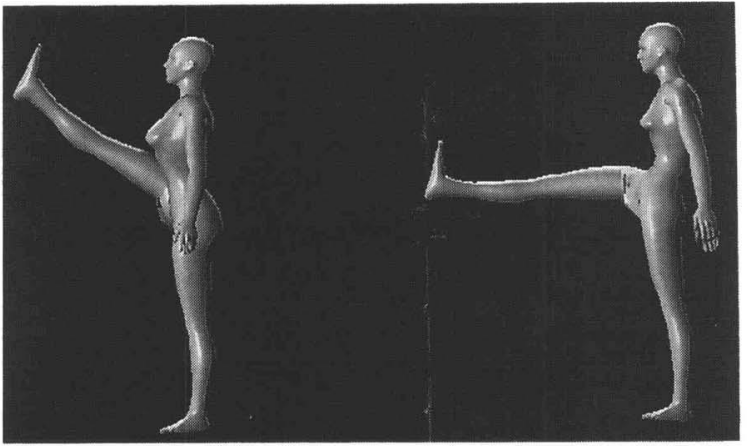

図 3 股関節屈曲運動が単独に起こる場合と, 腰椎屈曲を伴う場合

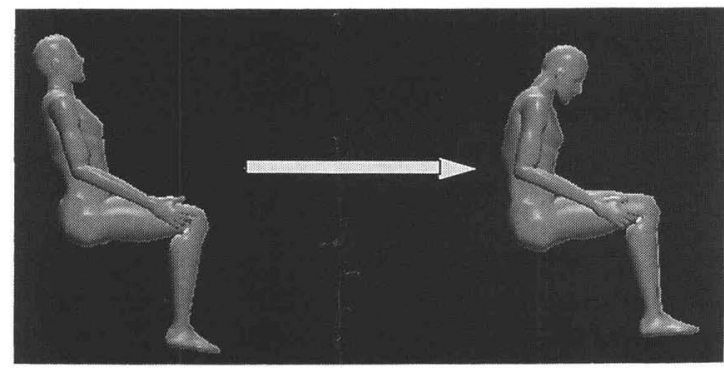

図 4 左：脊椎安定性良い 右：脊椎安定性悪い

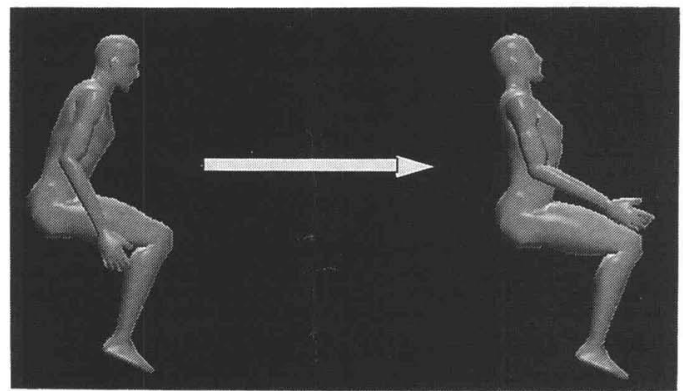

図 5 左：脊椎安定性良い 右：脊椎安定性悪い 
まま前傾するには，春柱起立筋とともに多裂筋などの深 層筋, 椎間関節の関節包, 棘上, 棘間などの䩲帯が協調 作用しなければならない。この時に筋力低下があると， 非収縮受動要素への mechanical stress は大きくなり, ク リープ現象を引き起こしたり,コラーゲン緎維の elongationを引き起こす結果となる。関節包であれば，滑 膜増殖などの結果にもなり得る。

従って, 静止しているのではなく, 日常動く人間を考 える場合には，必ず筋活動をチェックしなければならな いのではないだろうか。

\section{IV. ジャンパー膝}

スポーツ障害の代表としてジャンパー膝を例に考え る。ジャンパー膝では膝蓋靫帯〜大腿四頭筋への過剩な mechanical stressによりおこる。そのため, 運動量過多と 指摘されて, 安静をすすめられるケースが多い。しかし， 問題は何故膝蓋靫带に過剩な mechanical stress がかかる かと言う問題であり,この問題解決のみが原因療法とな り再発予防と結びつく。

ジャンパー膝で膝伸筋に過㮃なストレスがかかるケー スでは tight hamstrings を持ち, 骨盤後傾になっている例 が多い。足関節はやや内反位で背屈制限を有する。同時 に股関節は骨盤後傾からも解るとおり, 屈曲制限が必ず と言って良いほど存在する。特に疼痛の激しい側では上 記の身体特性が大きく作用している。腰椎前弯は減少し て, 立位から指を床に近づける動作では前屈制限がある。 制限がなければ，腰痛を持つ症例が圧倒的である。つま り，全身性の疾患と考えた方が良いように思う。この場 合の治療原則を表 2 に示す。

理学療法士の存在なくして語れないのはこの第 3 段階 において, mechanical stressに対する評価と治療が正しく できるかどうかにかかっていると思う。本症では筋〜腱 という能動要素への過剩ストレスであるから, 膝関節か ら上方向，頭部までの身体の重心の位置により，ストレ

表 2 ジャンパー膝に対する理学療法の段階

\section{第1段階：対症療法 RICE}

第2段階：障害部位訓練 大腿四頭筋ストレッチング レッグカール

第3段階：パフォーマンス向上訓練 膝伸展筋負荷低隇の全身コントロール
スが変化する。そのため, 股関節での屈曲により上部の 身体をより正しい位置に持っていくこと, あるいは足圧 中心が前方化することが重要となる。

\section{ACL 損傷}

次にスポーツ外傷の代表として ACL 損傷を例に挙げ る (表 3)。ACL損傷自体も身体重心後方化, 足圧中心後 方化により床反力ベクトルと重心に対するベクトルは身 体全体を後方回転することにより生ずると考えられる。 従って, 前述のジャンパー膝に共通した身体特性を有す ることが多い。ACL 損傷でも特に重要なのはやはり第3 段階であろう。特に反対側膝関節も緩い例では, 身体全 体の運動が特に重要である。但し, 観血療法であれば, 手術の影響が非常に大きい。ACLの起始・付着部位が生 理的位置でないと理学療法は厳しくなる。骨孔の問題な どからも推察されるように, 術前のACLの状態と同じ方 が良いことになる。骨盤に付着する筋を考える以上，膝 関節の生理的運動は最低限骨盤を見なければならない。 そののち, 身体全体の位置を考えることにより足圧中心 を考慮した運動療法が必要になる。身体重心後方移動は ACLに mechanical stress をかけることになる。

第3 段階では運動の量, バリエーションを増やすとと もに，「how to move」を指導する必要がある。このために はスポーツの運動特性もそうだが, それを行う身体運動 のメカニズムについて熟知する必要があると考えられる。

\section{VI. おわりに}

今後理学療法士の活躍は, 傷害に対する治療だけでは なくなる。disperformance, つまりスポーツ外傷や障害等 により生じた, スポーツ動作の能力低下を如何に克服す

表 3 ACL 損傷に対する理学療法の段階

\begin{tabular}{c}
\hline 第1段階: 術後管理 \\
再建勒带に対するリスク管理 \\
関節の保護 \\
炎症に対する理学療法 \\
第2段階: \\
障害部位訓練 \\
関節可動域訓練 \\
筋力増強訓練 \\
協調性訓練 \\
第3段階: パフォーマンス向上訓練 \\
\\
スポーツ動作の基礎となる運動のトレーニンク \\
身体の使い方のトレーニンク \\
\hline
\end{tabular}


ることができるかが, 重要になってくるのではないかと 考えられる。要するに, 1 力所の mechanical stressの上昇 は必ず他の部位の mechanical stressに影響を及ほしてい るということを評価し治療していく能力のことではない だろうか。

\section{文 献}

1) 福井 勉·他: スポーツ障害への運動コントロールと運動学 習理論の応用. 理学療法ジャーナル, 29:693-699, 1995.

2) 福井 勉:動作分析と運動連鎖一整形外科疾患をみるための 方法についてー. 理学療法ジャーナル, 32:237-243, 1998.

3）福井 勉: 膝関節固定化における身体運動が脛骨前方移動に 及汸す影響. 昭医学誌, 54:176-184, 1994. 